Notre Dame Law School

NDLScholarship

Journal Articles

Publications

1964

\title{
The Emergence of Law and Justice in Pre-Territorial Wisconsin
}

Donald P. Kommers

Notre Dame Law School, donald.p.kommers.1@nd.edu

Follow this and additional works at: https://scholarship.law.nd.edu/law_faculty_scholarship

Part of the State and Local Government Law Commons

\section{Recommended Citation}

Donald P. Kommers, The Emergence of Law and Justice in Pre-Territorial Wisconsin, 8 Am. J. Legal Hist. 20 (1964).

Available at: https://scholarship.law.nd.edu/law_faculty_scholarship/14

This Article is brought to you for free and open access by the Publications at NDLScholarship. It has been accepted for inclusion in Journal Articles by an authorized administrator of NDLScholarship. For more information, please contact lawdr@nd.edu. 


\title{
The Emergence of Law and Justice in Pre-Territorial Wisconsin
}

\author{
By Donald P. Kommers*
}

\begin{abstract}
$\mathbf{P}$ RIOR TO 1825, Wisconsin was largely an uninhabited wilderness, 1 though political jurisdiction had been exercised over the area since the sixteenth century. From 1512 to 1627 the sole claim over the area that is now Wisconsin was by Spain, whose jurisdiction was derived from the early discovery of Ponce de Leon. ${ }^{2}$ Though claiming hegemony over the old Northwest, Spain was never in actual occupation of the territory, so that the pattern of legal development which ultimately emerged in Wisconsin bore little or no imprint of Spanish culture.

Not until the middle of the next century were the rudiments of civil government forged in isolated pockets of the wilderness in the wake of French explorations into the territory of the old Northwest. France occupied the territory until February 10, 1763, when civil jurisdiction over Wisconsin passed to Great Britain pursuant to the Treaty of Paris negotiated at the conclusion of the French and Indian War. ${ }^{8}$ Under French occupation the Coutume de Paris
\end{abstract}

* Department of Political Science, University of Notre Dame. The author is grateful to the University of Wisconsin Law School for funds which made this research possible.

1 William H. C. Folsom who, in 1836, at nineteen years of age, began his career in the Northwest at Prairie du Chien, reminisces: "Our history of Fifty Years in the Northwest commences properly at Prairie du Chien in the years 1836-37. The entire country west and north was at that time but little better than a wilderness. Prairie du Chien was an outpost of civilization. A few adventurous traders and missionaries had penetrated the country above, planting a few stations here and there, and some little effort had been made at settlement, but the country, for the most part, was the home of roving tribes of Indians, and he who adventured among them at any distance from posts or settlements did so at considerable peril." Fifty Years in the Northwest (St. Paul: The Pioneer Press Company, 1883), p. 18.

2 Moses M. Strong, History of the Territory of Wisconsin From 1836 to 1848 (Madison: Democrat Printing Company, 1885), p. 214.

3 Wisconsin Historical Collections (Madison, 1888), XI, 36-46. See also Louise Phelps Kellogg, The British Regime in Wisconsin and the 
(known as the common law of France), ordinances of the Kingdom, and certain decrees of Canadian authorities constituted the major rules of civil conduct. ${ }^{2}$ But these were seldom invoked as civil law administration foundered upon the barbaric style of life which prevailed during the French era. In fact, no French courts were even established in the Northwest Territory. ${ }^{5}$

The Frenchman who migrated into the Wisconsin wilderness was a carefree and daring adventurer ; ${ }^{6}$ yet one of his greatest contributions lay in pacifying and civilizing the aborigine, ${ }^{7}$ a factor related to the flourishing fur trade which formed the economic basis of French rule in Wisconsin and became the chief stimulus of French Canadian penetration into the Northwest. The early settlements at Green Bay and Prairie du Chien were soon to be surrounded by small farms which developed in response to the daily needs of local traders. ${ }^{8}$ The point to remember is that these socioeconomic developments took place outside the framework of any organized structure of law.

But abuses soon crept into the fur trade as each trader tended to become a law unto himself. The immunity of the fur trader from official sanctions ended, however, when licenses were required of all who wished to engage in the fur trade and when military posts, garrisoned by disciplined troops, were constructed in the wilderness to supervise the activities of the traders. ${ }^{9}$ Thereupon the military post became the basic governmental unit of this early society. The commandant of each post exercised discretionary jurisdiction in all matters relating to disputes between traders as well as to relations between trader and Indian, and no independent judicial machinery existed to resolve disputes between these parties. The Coutume de Paris was always available if some reference to civil law was necessary, but there is little evidence that these laws were ever enforced in the northern posts and it is highly doubtful whether Green Bay and Prairie du Chien, the only settled areas in Wisconsin prior to 1763, were significantly affected by the French Civil Code. In fact,

Northwest (Madison: State Historical Society of Wisconsin, 1935), pp. 23-32.

4 See Fraser's Introduction to 1 Mich. Terr. Laws iii-xiv (1871).

5 See "Common and Statute Law in the Northwest Territories" in Wisconsin Annotations (1914), p. 1820.

6 See Reuben G. Thwaites, Wisconsin: The Americanization of a French Settlement (Boston and New York: Houghton Mifflin Company, 1908), pp. 62-84.

7 Folsom, op cit., note 1, supra, at 165.

8 Louise Phelps Kellogg, The French Regime in Wisconsin and the Northwest (Madison: State Historical Society of Wisconsin, 1925), p. 389. 9 Ibid., p. 366. 
military authority tended to become exceedingly and progressively arbitrary as post commandants proceeded to exploit their positions for purposes of self-aggrandizement. ${ }^{10}$

Literally hewing an existence out of the wilderness and living in unusual accord with the aborigine, Frenchmen were ill-disposed to object to official corruption. Historians have noted the difficulties involved in bringing political democracy to the French settlers of the old Northwest.11 Another writer suggests that the social amalgamation of the French and Indians was related to French disinterest in erecting governmental institutions under civilian control. Ferris reports that "while this policy of intimate association with the different tribes had strengthened the hold of the government upon the country, it also had tended to sink the Frenchman into a barbarian. Casting off the habits of civilization, he soon imbibed the notions, whims, and prejudices of his wild associates." 12 This experience, compounded by years of military rule, seems to have rendered the French wholly unaccustomed to the discipline of self-government.

But military authority did not cease immediately with Wisconsin's formal admission into the British Empire in 1763. Although civilian rule was established in the eastern provinces of newly acquired Canada, the British Board of Trade recommended that the new government's jurisdiction should not extend to the lands lying adjacent to the Great Lakes. ${ }^{13}$ The Board's chief interest in the western wilderness was in consolidating the fur trade, the success of which depended upon the good will and cooperation of the Indians; the British knew that Indian hostility would result from the establishment of civil government and the rapid settlement it would bring. ${ }^{14}$ These recommendations against the erection of civil government in the French-Indian country were officially sanctioned by the Royal Proclamation of October 7, 1763.15 Thus, in the early stages of British rule, Wisconsin continued to be governed by military rule

10 Ibid.

11 See Beverly W. Bond, Jr., The Civilization of the Old Northwest (Now York: The Macmillan Company, 1934), pp. 150-151.

12 Jacob Ferris, The States and Territories of the Great West (New York and Auburn: Miller, Orton, and Mulligan, 1865), pp. 77-78.

13 See Papers Relating to the Establishment of Civil Government in the Territories Ceded to Britain by the Treaty of 1763 in Adam Shortt and Arthur G. Doughty (eds.), Documents Relating to the Constitutional History of Canada 1759-1791 (2nd ed.; Ottawa: J. de L. Taché, 1918), Pt. I, 127-147.

14 Nelson Vance Russell, The British Regime in Michigan and the Old Northwest 1760-1796 (Northfield, Minnesota: Carlton College, 1939), p. 49.

15 Shortt and Doughty, op. cit., note 13, supra, 163-169. 
from garrisons located at Fort Edward Augustus (Green Bay) and Mackinac. Gradually, however, the small British minority grew in power and influence and resented the absence of civilian control and common law institutions. ${ }^{16}$

Pressures originating from the compelling attraction of inexhaustible riches of the Indian country, from incipient British plans to colonize west of the Alleghenies, and from the agitation of English settlers for civilized institutions, combined to produce the Quebec Act of 1774, which finally extended civil government over Wisconsin and other British territory around the region of the Great Lakes and in the Mississippi Valley. ${ }^{17}$ Wisconsin thus became an integral part of the Province of Quebec. One provision of the Act made the criminal law of England applicable throughout Quebec, but "in all Matters of Controversy, relative to Property and Civil Rights, Resort shall be had to the Laws of Canada, as the Rule for the Decision of the same." 18 American revolutionaries later attacked the provision of "abolishing the free System of English Laws in a neighboring Province, establishing therein an Arbitrary government." 19 Frenchmen, however, having little familiarity with English institutions, did not easily absorb the common-law, ${ }^{20}$ and thus, the provision might be regarded as a concession to French culture. The Crown also reserved to itself full discretionary authority to establish courts of criminal, civil, and ecclesiastical juris-

16 Reginald Coupland, The Quebec Act (Oxford: The Clarendon Press, 1925), pp. 44-47.

17 Shortt and Doughty, op. cit., note 13 supra, 570-576.

18 lbid., p. 573.

19 "Declaration of Independence," quoted in Henry Steele Commager (ed.), Documents of American History (5th ed.; New York: AppletonCentury-Crofts, Inc., 1949), p. 101.

20 William Renwick Riddell, Michigan Under Britigh Rule: Law and Law Courts 1760-1796 (Lansing: Michigan Historical Commission, 1926), p. 34. Moses Strong relates an incident illustrative of the French attitude: "On November 21, 1768 Col. Wilkins issued his proclamation for a civil administration of the laws of the country. For this purpose, he appointed seven magistrates or judges from among the people as a civil tribunal, to expound the principles of the common law of England. A term of this court was held December 6, 1768, at Fort Chartes, which was the first common law jurisdiction ever exercised in what, within twenty years, became the Northwest Territory of the United States. The court was a non-descript affair. It was a court of first and last resort-no appeal lay from it. It was the highest as well as the lowest-the only court in the country. The trial by jury, the French mind was unable to appreciate. They thought it very wonderful that the English should refer the determination of nice questions relating to the right of property to a tribunal 
diction within the Province. ${ }^{21}$ The American Revolution, however, prevented the implementation of these provisions in that part of the western territory embracing the present State of Wisconsin, and the change of sovereigns did not result in the establishment of judicial institutions. ${ }^{22}$

Finally, in 1788, Lord Dorchester issued a proclamation establishing four judicial districts in the Province of Quebec. ${ }^{23}$ Thus Wisconsin and Michigan, at that time included in one of the four districts, share a common legal development although in chronological terms Wisconsin received its court system years after the Michigan judiciary went into operation. A Court of Common Pleas and a Court of Quarter Sessions were established in the new district,24 but they administered no law west of Lake Michigan.25

In 1791 another institutional development affected the character of the fledgling judiciary; a proposal to divide Canada into two provinces-Lower and Upper Canada-materialized. Upper Canada embraced both Michigan and Wisconsin and was to have a legislative council of at least seven persons appointed by the Crown for life and a popular assembly of at least fifteen persons elected by land owners or rent payers. Under the Constitutional Act of 1791 the Governor and Executive Council, appointed by the Crown, were constituted a Court of Civil Jurisdiction for hearing and determining appeals. ${ }^{26}$

It should be noted that by 1790 Upper Canada was principally inhabited by British subjects habituated to English law and custom. At its first legislative session in 1792, the Parliament of Upper Canada repealed the provision of the Quebec Act making the laws of Canada applicable to civil and property matters; henceforth the laws of England were to apply. ${ }^{27}$

Other notable developments in judicial structure immediately followed. In 1792 trial by jury was introduced; in the same year a

consisting of tailors, shoemakers or other artisans and trades people, rather than to judges learned in the law. The attempt was a failure." Strong, op cit., note 2, supra, 60-61.

21 Shortt and Doughty op. cit., note 13, supra, 575-576.

22 Strong, op. cit., note 2, supra, 167-168.

23 Shortt and Doughty, op cit., note 13, supra, Pt. II, 953-954.

24 Riddell, op cit., note 20, supra, 52-61.

25 Consul W. Butterfield, "The Bench and Bar of Milwaukee," 5 Magazine of Western History 695-696 (March, 1887).

26 See "The Constitutional Act of 1791" in Shortt and Doughty, op. cit., note 13, supra, Pt. II, 1031-1051.

27 See "An Act Introducing English Civil Law Into Upper Canada" in Arthur G. Doughty and Duncan A. McArthur (eds.) Documents Relating to the Constitutional History of Canada 1791-1818 (Ottawa: C. H. Parmelee, 1914), pp. 83-84. 
provincial statute established a Court of Request with two or more justices of the peace who decided cases for the recovery of debts not exceeding forty shillings. In 1793 a Court of Probate, composed of the Governor and his associates, was formed for the Province as a whole, in addition to which the Governor was authorized to form within each judicial district a Surrogate Court to probate wills and grant letters of administration. A 1794 act established a Court of King's Bench, with original civil and criminal jurisdiction, and presided over by a chief justice and two associate justices. All records of the old Courts of Common Pleas were to be deposited in the Court of King's Bench. Appeals from judgments in cases involving more than one hundred pounds lay to the Court of Civil Jurisdiction; an appeal from this court lay to the Privy Council in cases exceeding five hundred pounds. Also, a District Court of limited jurisdiction was established in every district of the Province; these courts were given jurisdiction of all actions of contract for sums above forty shillings and not exceeding fifteen pounds, and were to be presided over by one or more appointed judges. In the western district, which included Wisconsin, the court was located in Detroit. Not one of these courts, however, actually operated in Wisconsin; indeed, except for a few justices of the peace, there were no separate courts west of Lake Michigan until Wisconsin became an integral part of Michigan Territory. ${ }^{28}$

In any event, the Jay Treaty marked the official and formal termination of British control over Upper Canada ${ }^{29}$ and by June, 1796, the area was brought within the exclusive jurisdiction of the Northwest Ordinance providing for the administration of the western lands. Significant was the fact that the assumption of United States jurisdiction over the Northwest did not result in the serious attenuation of British laws, customs, or institutions. ${ }^{30}$ The point to remember is that here in pre-territorial days under British rule lay the basic roots of the judicial system which ultimately emerged in Wisconsin.

The Northwest, prior to 1800 , was still largely an unsettled region. Given the opportunities for new experience on an open frontier, it seems remarkable that there was so little resistance to the wholesale importation of British customs and legal devices. Yet, English law was the only jurisprudential system with which most learned men of the time were familiar. Despite some colonial resistance to certain forms of English law subsequent to the Revolutionary

28 Ibid., pp. 85, 146-147, 155-158.

29 Commager (ed.), op. cit., note 19, supra, at 165 .

30 Strong, op. cit., note 2, supra, at 170. 
War, ${ }^{31}$ the common law and common law courts were absorbed into the legal systems of the original states and exercised a decisive influence upon the development of Wisconsin's legal system.

But the lack of frontier experimentation with judicial institutions may have been related to the prescriptions of the Ordinance of $\mathbf{1 7 8 7}$ which directed the erection of a court of three judges "who shall have a common law jurisdiction." Too, the inhabitants of the territory were guaranteed the benefits of the writ of habeas corpus, trial by jury, and "judicial proceedings according to the course of the common law." 32 Theory, however, was not supported by fact. In the territory's northern extremity, and in Wisconsin particularly, law administration was crude and the court system rudimentary, for here the directives of the Northwest Ordinance were largely inoperative. The reality of the situation was described as follows:

"Transgressions against the security of life and limb were by force of circumstances dealt with in a summary way, in order to restrain offenders from violations of the peace and good order. Under these circumstances the power conferred by the Ordinance of 1787, to promulgate civil and criminal law, could not be readily executed, for an employment of orderly procedure in the customary ways was materially hampered and restricted by the prevailing primitive state of affairs. Nor were the territorial judges and officers supplied with means to promulgate and enforce a system of procedure such as prevailed in older states and which had been evolved under more favorable conditions." 33

The only known judicial tribunals in Wisconsin during this early period (roughly between 1790 and 1820) were justice of the peace courts. The first civil commissions granted to officials in Wisconsin by United States authorities seem to have been issued to Henry M. Fisher and one Campbell, both justices of the peace, but no record of their deliberations exists if, indeed, they ever held court. Reed asserts that the first judicial functionary was Pierre Grignon of Green Bay, commissioned justice of the peace by Colonel Robert McDonald, British commander of the military post at Mackinac. ${ }^{34}$

The judges of these early courts apparently were of questionable probity and often ignorant of the refinements of common law,

31 Francis R. Aumann, The Changing American Legal System (Columbus: The Ohio State University Press, 1940), pp. 79-81.

32 Commager (ed.), op. cit., note 19, supra, 129-130.

33 Robert G. Siebecker, "The Supreme Court of Wisconsin Territory," 1912 Proceedings of the State Historical Society of Wisconsin (Madison, 1913), p. 223.

34 Parker McCobb Reed, The Bench and the Bar of Wisconsin (Milwaukee: P. M. Reed, 1882), pp. 7-8. 
for they seem to have administered justice in accordance with their own intuitive notions of right and wrong. Accounts describing the mode of frontier justice prevailing in Wisconsin around 1800 abound with tales as instructive as they are humorous. One of the most noted and colorful of these early justice courts was the one presided over by Charles Reaume of Green Bay. Reaume presumably held his original appointment under George III, but later was commissioned by the Governor of Indiana Territory after Britain's withdrawal from the Northwest. ${ }^{35}$ His primary source of legal materials seems to have been the French Civil Code and the customs of the Indian traders at Green Bay, although he is reported to have had a copy of Blackstone in his cabin. ${ }^{36}$ But these appear to have had little or no influence over him; often motivated by self-interest he was quite arbitrary in his decisions. ${ }^{37}$ Appeals from Reaume's decisions were seldom taken because of the expense and distance involved in taking such appeals all the way to Detroit. In addition, Reaume was

35 James H. Lockwood, "Early Times and Events in Wisconsin," Wisconsin Historical Collections (Madison, 1903), II, 105.

36 Milo M. Quaife, Wisconsin: Its History and Its People (Chicago:

The S. J. Clarke Publishing Company, 1924), I, 397.

37 Reed relates that in one case "a man was sued by a Frenchman on an account, and summoned to appear before Judge Reaume. The summons was returnable at two o'clock in the afternoon, but the defendant forgot the hour. Four o'clock arrived, when he bethought himself of his remissness. He immediately repaired to the hall of justice, first taking the precaution, however, to slip into his overcoat pocket a bottle of good old whiskey. On entering the ... chamber he found the cause decided against him, the plaintiff exulting in his success and the judge rigid and dignified-the defendant had defied his authority and disobeyed his mandate! In vain did the delinquent [defendant] attempt to thaw the ice of the judge's cold reserve and obtain a rehearing. Failing in all his efforts, the defendant rose from his seat, and approaching the door of an inner apartment invited the judge to follow. This he did reluctantly. When safely out of sight of the other party, the defendant slowly drew from his pocket the aforesaid black bottle and placed it on the table, where [there] were already glasses and water. The stern features of the judge suddenly relaxed. It was an easy matter to prevail upon him to taste the tempting beverage; it was, indeed, so good, that he repeated the dose, and like many other great men before him, lost his resentment in his love for good liquor. The judge and the defendant soon re-entered the justice hall, and the plaintiff, who was still present, was required to appear, when he was informed that the court had decided to grant a rehearing of the case. This was accordingly done, and after a brief examination the former judgment was revoked and judgment was entered against the plaintiff. The latter remonstrated in vain, stoutly contending that the judge had already decided the cause in his favor. All was cut short by the judge 
careful not to decide against traders financially able to take an appeal. ${ }^{88}$

These few scraps of early judicial history have some meaning in that they illustrate at least the potential willingness of the early pioneers to submit to judicial procedures in settling controversies. But as to disputes among themselves the traders frequently preferred to submit to the arbitration of fellow traders rather than to justices of the peace. ${ }^{30}$ It may be that even the rudimentary procedures of the justice courts constituted more formalization than the hardy pioneers were willing to endure, in addition to which there was, of course, the obvious corruption of Reaume's court. The traders' acquiescence in the arbitration device indicated some desire on their part for ordered relationships, the major function of any society's structure of law and justice.

One hopes that this focus upon civil adjudication does not obscure the important, if not major, role of military justice during this early period. Until 1824 law administration was a function of military authority as well as of the civil courts. ${ }^{40}$ In fact, the accounts of this period constitute, for the most part, military history; ${ }^{41}$ the Army and the Indian Office, both agencies of the United States War Department, shared a major responsibility in keeping the peace. ${ }^{42}$ It is reported that:

"From 1816 to 1824 , a period of eight years, although Wisconsin and a part of Michigan Territory were nominally under the protection of the flag of the Union, yet but little of parental care was bestowed upon her citizens in civil life by the General Government. The rule that bore sway was essentially military. No courts were organized, and offenders against the laws were either sent from remote parts of the settlement to Detroit for trial, or perhaps more usually suffered to escape punishment. The civil code was limited and but sparingly administered. But the military code, such as it was, more than supplied the deficiencies of the civil." 43

When Illinois was admitted to the Union in 1818, Wisconsin

declaring that 'his first decision was only that the plaintiff should win to lose.'" op. cit., note 34, supra, 10-11.

38 Ibid.

89 Ibid.

40 Charles R. Tuttle, An Illustrated History of the State of Wisconsin (Boston and Madison: B. B. Russell, 1875), p. 180.

41 See Henry Colin Campbell, Wisconsin in Three Centuries 16s4-

1905 (New York: The Century History Company, 1906), II, 121-211.

42 Alice E. Smith, James Duane Doty (Madison: State Historical

Society of Wisconsin, 1954), p. 92.

43 Wisconsin Historical Collections, op. cit., note 35, supra, at 84. 
was absorbed into Michigan Territory. ${ }^{44}$ The area west of Lake Michigan (Wisconsin) was divided into three counties; Brown, Crawford, and Michilimackinac.45 Courts of probate were immediately established in each county. ${ }^{46}$ The significance of these courts is underlined by the fact that a substantial portion of the Northwest Ordinance dealt with the acquisition and conveyance of property. To that end the Ordinance directed that "proper magistrates, courts, and registers" be appointed. These probate courts were the forerunners of the Wisconsin county courts.

Michigan later enacted a statute establishing in each county a court consisting of one chief justice and two associate justices, and possessing original jurisdiction in civil cases above the jurisdictional limitations of the justices of the peace where the matter in controversy did not exceed one thousand dollars. These county courts were also granted criminal jurisdiction over non-capital offenses. The county court act is compelling for its meticulous elaboration of practice methods and procedural technicality. ${ }^{47}$ The drafters were not writing on a tabula rasa; this enactment was virtually a carbon copy of similar statutes operative in Massachusetts, New Jersey, North Carolina, and Ohio. The Supreme Court of the Territory possessed original and exclusive jurisdiction over cases involving capital offenses and over all civil cases involving damages in excess of one thousand dollars. ${ }^{48}$ Appeals were allowed from the judgments of both county and probate courts to the Supreme Court sitting in Detroit. Chancery or equity jurisdiction was vested in both the Supreme Court and county courts, and both courts enjoyed full rule-making authority. 49

At this time there was no trained bar in Wisconsin and few lawyers were available for these newly created judicial positions.50 Yet they appear to have been filled by reputable citizens; the scanty

44 Civil government over Wisconsin subsequent to 1800 was exercised by Indiana, Michigan, Illinois, and Michigan Territories respectively. Wisconsin was a part of Indiana Territory from May 7, 1800 to January 10, 1805, Michigan Territory from January 11, 1805 to February 2, 1809, nlinois Territory from February 3, 1809 to December 2, 1818, and again by Michigan Territory from December 3, 1818 to July 4, 1836, when Wisconsin acquired independent territorial status.

451 Mich. Terr. Laws 325-328 (1818). Michilimackinac County included the northern part of present day Wisconsin and the upper peninsula of Michigan, while the southern half was divided into two counties, Brown and Crawford.

46 Ibid., pp. 341-344.

48 Ibid., p. 714. 49 Ibid., pp. 697-698.
50 Ellis Baker Usher, Wisconsin: Its Story and Biography (Chicago:

471 Mich. Terr. Laws 716 (1820).

The Lewis Publishing Company, 1914), I, 89. 
court records that are available fail to disclose any evidence of gross ineptitude or malfeasance in office. Nor were the courts greatly overworked. In a comment that tells us as much about the character of these early Wisconsin inhabitants as it does about the role of the courts, Usher states:

"It speaks well for the law-abiding character and friendliness of these communities that, for some years, courts of record found little to do. In Crawford County no term [of court] was held until May, 1823, when a grand jury failed to find any indictments, and the business of the court was confined to the granting of two tavern licenses. At the next term, a year later, a single offender was indicted, but he could not be found; and the next following terms were held respectively in 1826,1830 , and 1831 . While sessions of the court for Brown county were probably held earlier, the records show none until July 12, 1824." 51

Meager county court records suggest, in part, some of the difficulties involved in appealing from judgments of the county courts and in prosecuting serious cases in Wisconsin. It is important to note that nearly all appeals and cases above the jurisdictional limitations of the county courts had to be heard by the Supreme Court of the Territory sitting in Detroit. Consequently, prospective litigants and would-be-appellants found it practically necessary to forego resort to the courts for the enforcement of their legal rights because of the sheer physical and financial hardships incident to traveling long distances over rough territory.

To relieve litigants of the inconvenience of going all the way to Detroit, Congress in 1823 created a separate circuit court for the three counties west of Lake Michigan.52 President Monroe appointed James Duane Doty, a leading lawyer of his day, judge of the new court.53 The history of the Wisconsin judiciary might be said to begin with the Doty court; concerning tribunals before that time, Berryman asserts, there seems to be more tradition than history. ${ }^{64}$

51 Ibid.

623 U. S. Stats. 722-723 (1823). The operation of the Michigan circuit court system established by the Michigan Territorial legislature in 1825 was never extended to Brown, Crawford, and Michilimackinac counties. The 1823 act creating a distinct court in these counties obviated that necessity. It should be noted here that the judges of the Supreme Court of Michigan also acted as judges of the Michigan circuit courts. Each judge would travel his circuit conducting trials and then all would meet as the Supreme Court when hearing appeals from the circuit courts. See 2 Mich. Terr. Laws 265-266 (1825).

53 John Berryman, History of the Bench and Bar of Wisconsin, (Chicago: H.C. Cooper, 1898), I, 55.

54 Ibid. 
The new circuit court was granted jurisdiction within the three counties previously possessed by the Supreme Court of Michigan Territory. In addition, the circuit court was granted jurisdiction concurrent with the county courts, and was empowered to hear all appeals at law or in equity from county court judgments. But the circuit court was not permitted to hear cases in admiralty or maritime jurisdiction, or cases involving the United States as a party. Doty was required to ride circuit by holding one term of court in each of the three counties every year at a specified time and place. The independence of the court was limited by the fact that the Supreme Court of Michigan retained the power to issue writs of error to Doty's court in all civil cases; in criminal cases there was no appeal from his court. ${ }^{85}$

Operationally the circuit court left something to be desired even though it filled a serious gap in the structure of the early judiciary. Congress apparently toyed with the idea of creating, instead of the circuit court, a new federal district court or a nisi prius system. (Historically nisi prius courts were held by itinerant judges who held jury trials over issues of fact in districts where the causes of action originated, and were to be distinguished from appellate courts. In the American territories the judges would meet separately at nisi prius to hold trials and then convene en banc as an appellate tribunal to review appeals from judgments at trial on matters of law.) That both these options were rejected in favor of a single court presided over by a single judge with far-flung jurisdiction was a policy decision which influenced the future development of the Wisconsin judiciary. The rejection of the former alternative, in removing the court from effective federal judicial review, expressed the willingness of the national government to give the court maximum independence in local matters, while the rejection of the latter alternative withdrew the court's administration from the realm of collective judicial responsibility. ${ }^{56}$

Whatever its deficiencies, Doty's court, as Milo M. Quaife observed, marked Wisconsin's passage, "metaphorically speaking, from the medieval to the modern age of things judicial." 57 Doty, a learned lawyer, was the first judge to bring to the judicial process a fairly high level of sophistication. He has been credited with introducing into his court all the procedures of the common law ${ }^{58}$ and he

553 U. S. Stats. 722 (1823).

56 See William Wirt Blume, "Circuit Courts and the Nisi Prius System: The Making of an Appellate Court," 38 Michigan Law Review 316 (January, 1940).

57 Quaife, op. cit., note 36, supra, at 401.

58 Butterfield, op cit., note 25, supra, at 699 . 
insisted upon rigid formality in his court. ${ }^{59}$ Although some settlers, like the French traders whose common law marriages to Indian women were upset by Doty's insistence that these relationships be legally sanctioned, viewed with dismay the establishment of regularly organized courts, most frontiersmen appeared satisfied with the dispatch of legal proceedings in his court and were eager to invoke the sanction of that tribunal to protect their interests. ${ }^{60}$ The business of the Doty court reflected a society just beginning to structure itself. Liquor traffic violations, creditor-debtor actions, conflicts between civil and military authorities over the occupation and use of land, and conflicts over land boundaries constituted a good portion of the court's civil business while the criminal docket was mostly taken up with cases involving illicit cohabitation, the selling of liquor to Indians, assault and battery, larceny, and murder, though reportedly the last three offenses were rare. ${ }^{81}$ The relative importance of the civil as compared to the criminal docket would seem to indicate, contrary to popular impressions, that the early pioneer was, in general, a law-abiding citizen. Indeed, human survival on the frontier demanded a high degree of toleration and cooperation, and it appears that one of the judicial system's chief functions was to give stability to this structure of cooperation.

As time passed the inadequacies of the Doty court became more and more apparent, and the administration of that tribunal was soon to work a reciprocal influence upon the course of political development. Out of the anomalous relationship of Doty's court to the Supreme Court of Michigan Territory evolved agitation for a separate and distinct territorial government west of Lake Michigan. A popular petition addressed to United States Senator Thomas B. Benton from Wisconsin residents read:

"The situation of this District [western Michigan] is essentially different from that of the residue of the Territory, and requires altogether a different system of Laws. It is considered the people of this Country ought, under no circumstances to be compelled to go to Detroit for justice; yet the Supreme Court of the Territory has exclusive jurisdiction over all cases arising in this District under the Revenue Laws of the United States, of admiralty and maritime jurisdiction, and, generally, of all cases in which the United States are plaintiffs. It has also concurrent jurisdiction with the circuit

60 Smith, op. cit., note 42 , supra, at 87.

60 Ibid., p. 72.

61 Out of forty-five indictments brought in one special term of court in Green Bay, only one was for murder and very few for assault, battery, or larceny. Twenty-eight of these indictments were for illicit cohabitation. See Tuttle, op. cit., note 40, supra, at 185 . 
court over all offenses committed within the Indian country. It is also a court of Error in all civil causes, and a court of Appeals in all suits in Chancery. These several jurisdictions vitally affect the interests of your pets. [petitioners], and they believe the insufficiency, and, in fact, injustice, of the present judiciary system is so apparent, that they deem it sufficient to advert to it without comment. They presume it would be contrary to the first principles of jurisprudence and of government, to establish two independent judicial tribunals with equal powers, but acting under different laws, in the same state or territory." ${ }^{2}$

It was Doty himself who then proceeded to draft a bill for organizing Wisconsin Territory with a judiciary to be composed of a supreme court, three district courts, and justices of the peace, ${ }^{63}$ but it received scant congressional attention. Although territorial status for Wisconsin was delayed for another decade, these grievances undoubtedly contributed to the ultimate establishment of Wisconsin as a distinct political and juridical unit.

The structure of law and justice in early Wisconsin played a significant role in disciplining the society and in influencing the future course of institutional development. The readiness, if not eagerness, of frontiersmen to "go to court" when their interests were threatened was not without meaning. If frontier justice in its administration by civil courts prior to territorial days was crude, simple, and efficient, conforming generally to very broad principles of equity and fair play, still men were becoming accustomed to the idea of litigation in courts of law, a distinct advance in the effort of men to make themselves civilized. Here law courts were just beginning to play a constructive role as law-abiding habits were slowly being instilled in the people. But human nature exercised a reciprocal influence. The evolution of the early judiciary partially represented man's insatiable longing to be let alone and to get on with his work. While a wilderness was being conquered, men sought material possessions. But even the pursuit of self-interest requires a modicum of legal control where the interests of others are also at stake. Most societies, however primitive, are in need of social controls, however rudimentary, to resolve and ameliorate conflict. Any assessment of such controls in pre-territorial Wisconsin cannot possibly ignore the contributions of these early law courts to the life of society.

62 Papers of James Duane Doty, Wisconsin Historical Collections (Madison, 1895), XIII, 222-224.

63 Ibid., pp. 227-235. 